\title{
Do Rio de Janeiro (1955) à Aparecida (2007) Um olhar sobre as Conferências Gerais do Episcopado da América Latina e do Caribe ${ }^{l}$
}

Prof. Dr. Pe. Ney de Souza

\section{RESUMO}

O artigo realiza um percurso sintético e analítico sobre as Conferências do Episcopado latino-americano. Apresenta a preocupação com a realidade e a pastoral da Igreja na América Latina. Essa visão de conjunto possibilita reconhecer uma Igreja vibrante, especialmente no pós Concilio Vaticano II, enfrentando os desafios externos e internos para sua missão de anunciadora e testemunha de Jesus na construção do Reino de Deus.

Palavras-chave: Catolicismo, América Latina, Episcopado, Conferências.

\begin{abstract}
The article realize a synthetic route and analytic about the Conferences of the Episcopate Latin-American. It presents the preoccupation with the reality and the pastoral of the Church in Latin America. This vision, as a whole, makes possible to recognize a vibrating Church, specially, after Vatican Council II, facing up to the outer and inner challenges for its mission announcer, and witness of Jesus in the construction of the God kingdom.

Key-words: Latin American, Episcopate, Conferences.
\end{abstract}

1 Este texto é resultado do estudo realizado com os alunos Alex Villas Boas, Atta Achille, Haruo Matsuda, José Ruy Gonçalves Lopes, Laurinda Terezinha Duarte, Nei Márcio Oliveira de Sá e Nilton Ficone Júnior, durante o desenvolvimento da disciplina História da Evangelização na América Latina, segundo semestre de 2007 no Programa de pós-graduação em Teologia da Pontifícia Faculdade de Teologia Nossa Senhora da Assunção.. 


\section{INTRODUÇÃO}

Uma das maneiras pelas quais o catolicismo da América Latina e do Caribe tem utilizado para refletir sua missão evangelizadora são as Conferências Gerais do Episcopado. A cada década, desde 1955, estas reuniões de bispos procuram conhecer e estudar a realidade do momento, refletindo sobre ela a luz da fé, buscando encontrar os horizontes e caminhos para o anúncio de Jesus Cristo aos homens e mulheres do continente.

As Conferências Gerais têm por característica essencial a reflexão pastoral. Em suas discussões não entram os assuntos dogmáticos, ligados às verdades da fé. A discussão pastoral tem sua origem na análise profunda das realidades social, política, econômica, cultural, religiosa e eclesial. Há também contribuição das outras ciências, na presença de assessores e peritos que fornecem elementos para uma análise crítica, precisa e atenta à realidade.

Quando se trata de reflexões pastorais para os continentes, também é preciso citar outra modalidade de reuniões de bispos: os Sínodos Continentais criados pelo Papa João Paulo II. Estes funcionam num papel consultivo e terminam com uma Exortação pós-sinodal, escrita pelo próprio Papa e não pelos bispos. O Papa pode aproveitar (ou não) os subsídios, reflexões e contribuições feitas nestas reuniões. De certa forma, o resultado de um Sínodo traduz um pensamento mais centralizado na figura do Romano Pontífice.

As Conferências Gerais também recebem grande influência do Papa. É ele quem as convoca, nomeia seus presidentes, envia os representantes da Cúria Romana e aprova (ou não) a participação dos delegados eleitos pelos bispos em nível local. Os trabalhos das Conferências Gerais do Episcopado são orientados através de seu Discurso Inaugural, têm papel importante nas discussões. Por fim, o Documento Final de uma Conferência Geral depois de votado pelos bispos participantes, é submetido à sua aprovação para publicação. Este Documento Final é obra dos membros da Conferência, diferente do resultado de um Sínodo, assinado pelo Papa, exclusivamente.

Esta pesquisa pretende apresentar uma visão panorâmica dos resultados das Conferências Gerais do Episcopado Latino-Americano e do Caribe. Iniciar-se-à com uma análise do contexto, da organização da Conferência Episcopal Latino-Americana (CELAM) e do documento final da $1^{\text {a }}$ Conferência Geral realizada no Rio de Janeiro, Brasil, em 1955. 
Na seqüência, serão apresentados dados da $2^{a}$ Conferência Geral que aconteceu na cidade de Medellín, Colômbia, em 1968. Acontecida pós-Concílio Vaticano II, utilizou o método da Ação Católica, Ver- Julgar- Agir, partindo da realidade latino-americana que vivia grandes turbulências políticas, econômicas, sociais e culturais em seus países. Esta Conferência marca diante da injustiça social existente e violação dos direitos da população, uma posição profética da Igreja Católica.

A seguir, este artigo apresenta aspectos fundamentais do Documento de Puebla, fruto da $3^{a}$ Conferência Geral. Sob o impulso da Exortação Apostólica Evangellii Nuntiandi, do Papa Paulo VI, proclama uma Igreja que testemunha, proclama, celebra e atua na promoção da justiça, amor, pobreza num processo dinâmico e permanente de evangelização².

Em 1992, na cidade de Santo Domingo, República Dominicana, aconteceu a $4^{\text {a }}$ Conferência Geral. Para este momento marcado por incertezas sociais, políticas e eclesiais será feita uma análise da Eclesiologia e da Missiologia presente no Documento Final e o contexto da Nova Evangelização, no final do século $X X$.

Finalmente, sob o tema "Discípulos e missionários de Jesus Cristo, para que nossos povos nele tenham vida! Eu sou o caminho, a verdade e a Vida" (Jo 14,6), será analisada a Igreja e Missão na V Conferência Geral do Episcopado Latino Americano e Caribenho, realizada em Aparecida, Brasil, em maio de 2007.

Este estudo coleta dados para uma compreensão e reflexão da caminhada histórica da Igreja Latino-americana e caribenha, mostrando as formas pelas quais se procurou dar uma resposta pastoral a cada tempo.

\section{A $1^{\text {a }}$ CONFERÊNCIA GERAL DO EPISCOPADO LATINO- AMERICANO - RIO DE JANEIRO, 1955}

\section{0 Contexto}

O Papa Pio XII, visando incrementar a ação evangelizadora da Igreja, em 29 de junho de 1955, através da Carta Ad Ecclesian Christi, convoca a

2 PAULO VI. Evangelli Nuntiandi. Exortação apostólica sobre a evangelização no mundo contemporâneo. Dezembro de 1975. n. 78. 
Conferência do Episcopado Latino-Americano. Para este Pontífice era necessário "combinar um plano e métodos concretos para realizar com solicitude e competência, tudo quanto as necessidades dos tempos exigem"3.

É necessário mencionar o Concílio Plenário da América Latina realizado em 1890, em Roma ${ }^{4}$. O seu objetivo era fortalecer a unidade da Igreja nas nações latino-americanas e isto proporcionou certa tomada de consciência de que a América Latina constituía uma unidade. Não trouxe, entretanto, novidades teológicas, mas unificaram-se as diretrizes sobre a disciplina eclesiástica a ser adotada nos trabalhos das dioceses ${ }^{5}$.

Vive-se na Europa o pós-guerra, período em que, seguramente, influenciará movimentos vocacionais e missionários.

\section{A CONFERÊNCIA DO RIO DE JANEIRO}

O tema central dessa Conferência Geral do Rio de Janeiro foi "a evangelização como defesa da fé e das vocações e a preparação do clero". Teve como presidente o Cardeal Adeodato Giovanni Piazza, Secretário da Sagrada Congregação Consistorial. Essa Conferência criou o CELAM (Conferência Episcopal LatinoAmericana) com a autorização do Papa Pio XII.

Participaram da Conferência do Rio de Janeiro 37 arcebispos, 58 bispos, de um total de 66 arcebispos, 218 dioceses, 33 prelazias, 43 vicariatos e 15 prefeituras apostólicas na América Latina.

A Conferência foi organizada em sete comissões de estudos com a finalidade de refletir os seguintes temas: clero e auxiliares do clero (religiosos); organização e meios de apostolado; protestantismo e outros movimentos anticatólicos; atividades sociais católicas; missões, indígenas e pessoas de cor; imigração e gente do mar.

AGOSTINI, Nilo. As Conferências Episcopais. São Paulo: Editora Santuário, 2007.

4 Para aprofundar confira SOUZA, Ney de. Um Concilio na virada do século - centenário do Concílio Plenário Latino-americano (1899-1999), in Revista de Cultura Teológica 27 (1999) 101-106.

5 PONTIFÍCIA COMISSIO PRO AMÉRICA LATINA. Los últimos cien anos de la evangelizacion en América Latina Centenário Del Concílio Plenário de América Latina. Vaticano Libreria Editrice Vaticana, 1999. 


\section{O DOCUMENTO}

Já no preâmbulo da Declaração afirma-se que "foram examinadas atentamente a situação religiosa de cada um dos países da América Latina". Consideram também, que "muito há de louvável e consolador nesta situação, tudo o que faz da América Latina um imenso continente que se orgulha da sua fé católica". Revela-se a preocupação com "as deficiências e dificuldades que nascem dos peculiares problemas religiosos de nossas Nações e as que provêm dos movimentos anticatólicos que tendem a intensificar-se neles"6 como também "o angustiante problema, sobretudo, da escassez de ambos os cleros em todos os países do Continente".

É uma Conferência muito preocupada com aspectos da vida intra-eclesial na América Latina. Os temas sociais serão abordados superficialmente.

Concernente ao tema central, a Declaração logo em seu início, assim expressa: "A Conferência teve como objeto central de seu trabalho o problema fundamental que aflige as nossas Nações, a saber: a escassez de sacerdotes. A Conferência estima que a necessidade mais urgente da América Latina é o trabalho ardente, incansável e organizado em favor das vocações sacerdotais e religiosas (...) mediante uma ativa e perseverante campanha vocacional". Vale salientar que a partir de então, tiveram início nas várias dioceses do Continente a Obra de Vocações Sacerdotais, até hoje influenciando as Pastorais ou Serviços Vocacionais.

Não se deixa porém, de recordar e valorizar os leigos, sobretudo os que fazem parte da Ação Católica e outras associações, "dos que militam em uma ou outra organização de apostolado, com plena submissão às diretivas e disposições dos Romanos Pontífices e da Sagrada Hierarquia". Mas, imediatamente, manifesta-se a preocupação com a Instrução Religiosa do povo, sobretudo pela escassez do clero.

Sobre as referências do âmbito social a Declaração menciona "o grito mais fundo da humanidade e que no mundo de um Deus justo chama a justiça e a fraternidade?" A referência vai além, fazendo algumas constatações:" O panorama social que apresenta o Continente Latino-americano nos permite advertir (...) que muitos de seus habitantes -especialmente entre os

6 Declaração dos Cardeais, Bispos e demais Prelados representantes da hierarquia da América Latina reunidos na Conferência Episcopal do Rio de Janeiro. 
trabalhadores do campo e da cidade - vivem ainda em uma situação angustiante. Tão deplorável condição de vida material, que põe evidentemente em perigo o bem-estar geral das nações e seu progresso".

A presença ativa da Igreja a fim de influir no mundo sócio-econômico, orientando-o com a luz de sua doutrina há de se realizar em três formas: iluminação (difusão da doutrina social), educação (sobretudo a educação católica e a instrução religiosa) e a Ação (particularmente do laicato católico, bem instruído e bem formado).

As questões sociais são mencionadas numa perspectiva superficial e própria do contexto da época. "Ao fazer sentir a presença da Igreja na solução dos graves problemas da justiça social, não se esqueça o dever de atender adequadamente às necessidades da população indígena". Tudo isto evidentemente numa perspectiva missionária correspondente à época: "que o índio se incorpore com honra no seio da verdadeira civilização. $O$ trabalho das missões entre os infiéis enche as páginas mais belas da história da Igreja na América".

Há de se notar nas poucas páginas da Declaração, alguns avanços de uma Conferência preocupada mais com assuntos ad intra que influenciaram em grandes temas da atualidade como a Pastoral Indigenista, os Conselhos de Justiça e Paz, oriundos da Doutrina Social da Igreja e a forte inserção dos leigos no mundo do trabalho e da política como agentes de evangelização. Foi esta Conferência sem dúvida (apesar de controvérsias), um grande primeiro passo na unidade da evangelização da Igreja da América Latina.

\section{A $2^{\text {a }}$ CONFERÊNCIA DO EPISCOPADO LATINO-AMERICANO - MEDELLÍN (1968)}

A segunda Conferência Geral do Episcopado Latino-americano foi aberta por Paulo VI , por ocasião do XXXIX Congresso Eucarístico Internacional em Bogotá, em 24 de agosto de 1968. Realizou-se em Medellín, na Colômbia

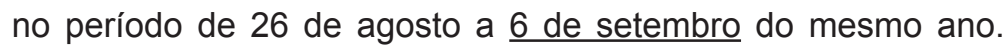

A Conferência de Medellín opera uma transformação na vida da Igreja e se torna uma reverência na vida eclesial do continente.

Com o tema: A Igreja na atual transformação da América Latina à luz do Concílio, Medellín situa-se na linha de duas constituições do Concílio do 
Vaticano II, a Gaudium et Spes e Lumen Gentium e, está em conformidade com a encíclica Populorum Progressio. Três foram os grandes temas de Medellín: Promoção humana; Evangelização e crescimento na fé; Igreja visível e suas estruturas. Foram produzidos 16 documentos, no horizonte dos três grandes temas citados: I) Justiça, Paz, Família, Demografia, Educação, Juventude. II) Pastoral popular, Pastoral de elites, Catequese, Liturgia. III) Movimentos de Leigos, Sacerdotes, Religiosos, Formação do Clero, Pobreza da Igreja, Pastoral de Conjunto, Meios de Comunicação. Os 16 documentos têm uma grande preocupação pastoral dos bispos diante da realidade do continente e todos terminam com orientações práticas.

Medellín parte da realidade social, fazendo um estudo atento da realidade tanto econômica, política e social quanto eclesial do continente latinoamericano e caribenho (ver). O segundo passo consistiu em identificar as interpelações que brotavam da realidade, analisando-as à luz da palavra de Deus do Vaticano II e do magistério e da experiência de toda a igreja. (julgar) $O$ terceiro passo foi o de propor pistas de ação pastoral, visando transformar no sentido do reino de Deus e da libertação dos pobres, a realidade atravessada por estruturas de pecado e pelo clamor e esperança dos pequenos (agir).

O objetivo mais amplo dos acontecimentos de 1968, era a construção de um mundo novo. As lutas e protestos de 1968 apontavam transformações profundas de estruturas e valores, valorização dos direitos humanos e democráticos, libertação dos oprimidos, rupturas com tradições opressoras e as alianças da igreja, e revolução do comportamento sexual. Ganharam grande repercussão os documentos sobre a Justiça, a Paz e a Pobreza da Igreja. Diante da relevância e impacto desses documentos, elementos característicos de Medellín foram as reflexões sobre pobreza e libertação.

O Episcopado Latino-americano não pode ficar indiferente perante as tremendas injustiças sociais existentes na América Latina que mantêm a maioria de nossos povos numa dolorosa pobreza e que, em muitíssimos casos chega a ser miséria inumana. Um surdo clamor brota de milhões de homens, pedindo a seus pastores uma libertação que não Ihes advém de parte nenhuma ${ }^{7}$.

7 Medellín, 14,1-2

ReVista de Cultura TeOlógicA - v. 16 - N. 64 - JUL/SET 2008133 
Como resposta a este clamor, propõem os bispos:

"Queremos que a Igreja da América Latina seja evangelizadora e solidária com os pobres, testemunha do valor dos bens do Reino e humilde servidora de todos os homens de nossos povos". [...] O mandato particular do Senhor que prevê evangelização dos pobres deve levar-nos a uma distribuição tal dos esforços e do pessoal apostólico que deve visar, preferencialmente os setores mais pobres e necessitados ${ }^{\wedge}$.

Nada marcou mais a Igreja latino-americana como a formação, organização das comunidades eclesiais de base (CEBs). A importância da ação das CEBs se verifica na união entre fé e vida buscando na opção de fé os princípios e valores que é preciso defender para que se estabeleça a justiça na sociedade e, os pobres tenham seus direitos respeitados.

O tempo de Medellín foi o das "vozes proféticas". Os sinais acolhidos e emitidos por Medellín, a proximidade ao contexto dos pobres, a necessidade de transformações e a discussão adulta sobre o projeto da humanidade permanecem tarefas permanentes. A profética opção pelos pobres de Medellín, necessita de uma segunda opção pela plena participação dos pobres, na reconstrução da sociedade e na reformação constante da Igreja. O anúncio explícito de que a causa dos pequenos e excluídos pode ser vitorioso faz parte do querígma missionário.

Foi em Medellín que nasceu o pensamento cristão e teológico latinoamericano, vivido na práxis pastoral da Igreja e na teologia que se denomina Teologia da libertação ${ }^{9}$. Medellín fez também com que a classe média se sentisse presente na evangelização com a organização da classe média, para que seja motor de mudança de transformação da sociedade. Para ter conhecimento, consciência crítica, é necessário ter condições econômicas ${ }^{10}$.

8 Méd.14,8-9

9 Cf. PADIN, C; GUTIÉRREZ,G; CATÃO, F. Conclusões da Conferência de Medellín -1968. Trinta anos depois, Medellín é ainda atual? São Paulo: Paulinas, 1998, p.277. Para um histórico da Teologia da Libertaçao, confira GONÇALVES, P. S. L. Teologia da Libertaçao um estudo histórico teológico, in SOUZA, Ney de. Temas de Teologia Latino-americana. Sao Paulo, Paulinas, 2007, 167-209.

10 Cf. MORÁS, F. Evangelização das classes médias e solidariedade com os pobres:: o legado de Medellín. Revista Eclesiástica Brasileira, Petrópolis,v.58, n.232, p. 787-821, dez. 1998. 
Segundo Oscar Beozzo ${ }^{11}$, Medellín apresenta algumas lacunas: a ausência de uma perspectiva histórica, o escasso recurso a palavra de Deus e pouca uniformidade sobre a noção de cultura e educação.

Em suas igrejas particulares, surgiram figuras de pastores que souberam a partir da herança do Concílio Vaticano II e de Medellín, caminhar profeticamente com seu povo, de modo particular com os pequenos e pobres, de maneira corajosa, na defesa dos seus direitos e na promoção de sua dignidade e libertação. Vários deles, como Mons. Enrique Angelelli da Argentina, Mons. Oscar Arnulfo Romero de El Salvador, Juan Jose Gerardi Conedera da Guatemala, ao lado de milhares de outros cristãos, militantes, religiosos, sacerdotes, que sofreram o martírio, por fidelidade ao evangelho e aos pobres e pequenos. Eles são como luzes que ilumina e anima a caminhada da igreja latino-americana na experiência do Concílio e principalmente no assumir em Medellín, na perspectiva mais ampla de todo o povo de Deus, seu próprio rumo e construção ${ }^{12}$.

\section{A 3 CONFERÊNCIA GERAL DO EPISCOPADO LATINO- AMERICANO - PUEBLA (1979)}

Evangelização no presente e no futuro da América Latina foi o tema da Conferência de Puebla. Com efeito, tratou-se da profunda identidade da Igreja, de sua missão essencial e fundamental que é nada mais que proclamar o Evangelho, hoje e amanhã, aos povos latino- americanos, animados pela esperança e ao mesmo tempo torturados no mais profundo de seu ser pelo desprezo em sua dignidade ${ }^{13}$.

Mesmo se debruçando sobre o Vaticano II, é bom mencionar que este tema de Puebla tinha sobretudo, como pano de fundo, a Exortação Apostólica Evangellii Nuntiandi, de 8 de dezembro de 1975, do Papa Paulo VI. Diante do grito de esperança dos povos da América Latina, de suas necessidades e dos desafios sociais, a Igreja precisava tomar uma postura profética dando um grande passo avante no que faz sua essência, a saber,

11 Cf. BEOZZO, J.O. Medellín: Inspiração e raízes. Revista Eclesiástica Brasileira, Petrópolis, v.58, n 232, p.844-849, dez. 1998

12 Cf. Ib. p. 849-850

13 Cf. DOCumentos Do CELAM. Conclusões do Rio de Janeiro, Medellín, Puebla e Santo Domingo. , Coleção DOCUMENTOS DA IGREJA. São Paulo: Paulus, 2004 p267 
sua missão essencial, evangelizar a fim de oferecer resposta a quem procura. Para isso se requer de Puebla, uma Igreja que testemunha, proclama, celebra e atua o Evangelho com justiça, amor, pobreza, uma Igreja num processo dinâmico e permanente de evangelização, de tal forma que todo o cultural, o político, o econômico, o social, seja lido e discernido a partir do Evangelho ${ }^{14}$. Vale a pena mencionar que, conforme Puebla, os setores mais necessitados de evangelização foram: A família (em especial a mulher), a juventude, os camponeses, o mundo operário, os afro-americanos, os meios de comunicação social.

Um dos modelos para a ação evangelizadora proposto em Puebla foi o das Comunidades Eclesiais de Base (CEBs). Ressalta-se que, para chegar a uma verdadeira e autêntica ação evangelizadora de libertação dos povos latino-americanos, o espírito de comunhão e de participação deveria estar sempre presente na Igreja.

Assim, o outro conteúdo da missão da Igreja na América Latina no seu anúncio evangelizador, é a proclamação da salvação em Jesus Cristo presente na Igreja. Com efeito, a Igreja como Corpo de Cristo, comunhão e sinal de comunhão da humanidade com Deus e entre si, é convocada por um mesmo Cristo a prolongar seu Corpo no tempo, no espaço, isto é na história. Daí a insistência de Puebla por uma cristologia contextualizada ${ }^{15}$. Ainda conforme Puebla, a Igreja na ação missionária deveria educar os seres humanos na autêntica solidariedade a fim de superar todas as formas de injustiça, seja dentro como fora dela. Desta forma a Igreja ia conseguir integrar como membro, todo ser humano sem preconceito de raça nem de condição social, abrindo-se assim, a todas as camadas sociais e se comprometendo preferencialmente com os pobres e excluídos dando atenção às necessidades ${ }^{16}$.

A Igreja também é conduzida pelo Espírito Santo que nela está presente, dando-lhe sempre o impulso conveniente e necessário a fim de tomar permanentemente consciência de sua condição de Povo de Deus entre os

14 lbid., p.272

15 Ibid., p.273

16 LORSCHEIDER, Cardeal, A. A caminho da $5^{a}$ Conferência Geral do Episcopado LatinoAmericano e Caribenho Retrospectiva histórica. São Paulo: Edição Santuário Aparecida, 28. 
povos e peregrina na história da humanidade ajudando estes a superar suas dores e misérias.

Na verdade, Puebla não foi convocada para corrigir ou mudar o trabalho e as orientações pastorais dadas por Medellín. Bem pelo contrário como em Medellín, o problema da libertação esteve também presente em Puebla, mas acentuando-se desta vez, não só a libertação da opressão, mas a libertação para a comunhão e participação (Puebla 842).

Para isso, a Igreja tão sonhada na América Latina foi indicada em Puebla como uma "Igreja-sacramento de comunhão". Uma Igreja-serviço, prolongando no tempo, no espaço e na história o Cristo Servo de Javé. Uma Igreja missionária que anuncia alegremente ao homem de hoje que ele é filho de Deus em Cristo. É uma Igreja em permanente processo de evangelização que deve se empenhar pela libertação de todo o homem e de todos (o serviço da paz e da justiça, seu ministério essencial Puebla 1304) se inserindo solidariamente no ministério apostólico da Igreja Universal em íntima comunhão com sucessor de Pedro.

Em suma, uma Igreja que ajuda a construir uma nova sociedade em total fidelidade a Cristo e a humanidade, no Espírito Santo, denunciando as situações de pecado, chamando à conversão na ação transformadora do mundo ${ }^{17}$.

\section{ECLESIOLOGIA E MISSIOLOGIA EM SANTO DOMINGO}

A Eclesiologia e a Missiologia, constituem os dois eixos principais do modus operandi da caminhada do Povo de Deus, marcados pela comunhão e missão, onde ambas se retroalimentam. A comunhão experimenta uma nova forma de vida na Vida e, portanto, naturalmente missionária, na medida em que é proposta de vida nova. Assim, a missão por sua vez, anuncia e oferece aquilo que se experimenta na comunhão. A eclesiologia e missiologia de Santo Domingo querem apontar como a Igreja Latino Americana e Caribenha devem viver essa comunhão, a fim de melhor cumprir sua missão.

17 Ibid.pp. 88-92 


\section{ECLESIOLOGIA EM SANTO DOMINGO (1992)}

Sob esse prisma acima mencionado, pode-se dizer que a eclesiologia de Santo Domingo é marcada por um forte momento de inflexão ${ }^{18}$, aonde as configurações de uma nova eclesiologia vão se delineando numa outra já presente e bastante viva. Há um entrecruzamento de horizontes utópicos, que são chamados a reunir seus diferentes pressupostos metodológicos e culturais, em nome da comunhão de todo o Povo de Deus.

A eclesiologia presente era a da continuidade de Medellín e Puebla que caracterizou profundamente a Igreja Latino Americana e Caribenha com uma nota de Libertação. Sob o influxo do Concílio Vaticano II, de diálogo com seu tempo, a Igreja Latino Americana construiu seu próprio caminhar, vendo, julgando e agindo na realidade, a partir do Evangelho, onde percebeu que seu maior interlocutor contemporâneo era o pobre e assim optou em se fazer pobre com os pobres, como forma de comunhão com o projeto do Reino de Deus de ser sal da terra e luz do mundo, fazendo a diferença numa sociedade exploradora e alienada das causas sociais, bem como se tornava companheira de luta dos demais protagonistas.

Por outro lado, a nova eclesiologia vem marcada pelos acentos de um novo pontificado preocupado em reavivar a experiência cristológica da fé, resgatando na humanidade ética exemplar e evidente de Jesus de Nazaré, também sua divindade mistérica e não evidente, e por isso a Tradição da Igreja se viu no dever de salvaguardar o depositum fidei da "verdadeira" face de Cristo num momento multifacetado e "multifacetador" da cultura e da História. Tal enfoque foi chamado de Nova Evangelização, nova em seus "métodos", "expressão" e "ardor".

Destarte, as duas eclesiologias buscavam novos meios de atingir o ser humano contemporâneo para uma experiência com o Deus de Jesus Cristo, em suas realidades contextuais, fiéis ao "espírito" conciliar, contudo, dentro de competências diferentes, que nem sempre assimiladas de ambas as partes. Evidentemente, o Vaticano II provocou uma verdadeira "explosão" missionária nas Igrejas locais em seus respectivos contextos, e concomitante à missão, novas formas de comunhão com Deus e com a humanidade a fim

18 LIBANIO, João Batista. Igreja contemporânea; Teologia e Símbolo in Perspectiva Teológica, pp. 345-352; SANTOS, Beni dos. A identidade da igreja Latino-Americano de Medellín a Santo Domingo, pp. 7-17. 
de mostrar novos aspectos da face de Cristo. A Nova Evangelização com sua competência de Magistério pontifical ${ }^{19}$, preocupava-se em manter os traços identitários da cristologia presente na Tradição, já tão desfigurados por toda a cultura de uma época, o que imprimiu no Magistério e seus organismos a prática da disciplina ${ }^{20}$.

Não obstante, metodologicamente isso é muito saudável para a teologia que era convidada a reler a história em busca do essencial da fé cristã, identificando seus contornos próprios de cada época e que permaneciam anacronicamente como elemento dificultador de uma inculturação do Evangelho, como necessariamente ocorreu em momentos significativos do pensamento teológico católico e cristão, pois o mesmo se deu com o avanço do Evangelho para a cultura helênica, continuado nos Padres da Igreja com o contato da filosofia, de modo exponencial em Agostinho, como em Tomás de Aquino e a mudança paradigmática da filosofia e da ciência. Essa consciência estava presente nas duas propostas eclesiológicas, contudo, marcada pela ambigüidade humana, esse momento não fora sempre amistoso, o que acaba por dificultar a recepção do que o Espírito diz à Igreja no seu momento histórico.

Santo Domingo foi o momento em que a Nova Evangelização se colocou como instância crítica na caminhada da Igreja Latino Americana. Por um lado, em sua preocupação de manter o fundamental da fé na reflexão teológica, correu o risco de um eclesiocentrismo, por privilegiar a doutrina, sendo a Igreja porta-voz da Tradição e nesse sentido conservadora, não raro, em detrimento das semina verbi de outras realidades que se levantavam. Por outro lado, pôde servir de auxílio valioso na aproximação da eclesiologia em não se desvirtuar de sua própria identidade, se regendo pelo imperativo do Reino anunciado por Cristo e não por pólos ideológicos, podendo constituir-se assim, como reflexão crítica destes. Tal postura se verifica na opção metodológica de Santo Domingo ao esquema "Ver-Julgar-Agir", optou-se pela 1) Iluminação teológica, 2) Desafios Pastorais e 3) Linhas Pastorais, marcado por uma preocupação de maior articulação e coerência entre doutrina e vida. Ainda como instância crítica, Santo Domingo ficou conhecido também por seus silêncios ao não se pronunciar sobre a Teologia da Libertação, e

19 JOÃO PAULO II. Redemptoris missio, n. 82.

20 LIBANIO, João Batista. De Volta à Grande Disciplina, pp. 155-156. 
quase não mencionar a libertação em seu imaginário que é sistematicamente substituído pela "promoção humana" e "cultura de vida", contra a "cultura de morte" que substitui a expressão "cultura de morte". Contudo, seu silêncio é significativo, uma vez que não é sumário, não é condenatório, mas se insere na paciência histórica de verificar seus frutos, no exercício da missão.

\section{MISSIOLOGIA EM SANTO DOMINGO (1992)}

A Missão em Santo Domingo é marcada pela preocupação na falta de coerência (n. 44) dos cristãos que inclusive é vista como uma das diversas causas que geram a pobreza do continente (n. 161) e, portanto, a missão em Santo Domingo começa na santidade (n. 32), caminho iluminado pela coerência entre doutrina e vida cristã, que permite conhecer a Cristo Ressuscitado dando novo sentido à vida e abrindo novos horizontes de esperança ao ser humano pelo anúncio de seu Reino que é "comunhão de todos os seres humanos entre si e com Deus" (n. 5). Santo Domingo assume o "evangelizar a partir de uma profunda experiência de Deus" (n. 91), onde toda a doutrina adquire sentido (n. 21) e só assim é possível fazer da evangelização um trabalho de " promoção humana" e "inculturação" dos valores cristãos na sociedade (n. 31).

A priori, a "promoção humana" é vista como "Dimensão privilegiada" da Nova Evangelização, onde a Doutrina Social da Igreja é chamada a ser conhecida como verdadeiro "canto à vida" (n. 162), chamando a atenção para a questão dos Direitos humanos (nn. 164-168), da Ecologia (nn. 169-170), da terra como dom de Deus que todos têm direito (nn. 171-177) ao fato do empobrecimento (nn. 178-181) ao problema do desemprego e das condições trabalhistas (nn. 182-185), às migrações e turismo (nn. 186-187), à ordem democrática (nn. 190-193), à Nova ordem econômica (nn. 194-203) ligada à necessidade de uma integração latino-americana (nn, 204-209), todas essas realidades são tidas como "sinais dos tempos" onde a Igreja deve levar o Evangelho. Porém, pede uma especial e urgente atenção à questão dos problemas da família (nn. 210-227).

O meio privilegiado que Santo Domingo adota para a promoção humana é o anúncio do Evangelho, é a "inculturação", pois toda cultura comporta um modo de ser e de viver que deve ser iluminado pelos valores cristãos, pois Cristo é a medida de toda a humanidade ( $n$. 231), tendo particular 
preocupação com a cultura moderna (nn. 252-260) que pervade as culturas, pedindo assim que a Nova Evangelização fosse entendida como um plano global de inculturação dos valores do Reino, na cultura do evangelizado, sem contudo, perder de vista que a medida de toda cultura se encontra no modo de ser e de viver de Cristo, a ser seguido pelos cristãos, e iluminados em três grandes mistérios da salvação: Natividade que à luz da encarnação leva o evangelizador a partilhar sua vida com o evangelizado; Páscoa que através do sofrimento purifica os pecados; e Pentecostes permite que todos entendam em sua própria cultura, as maravilhas de Deus (n. 230).

\section{CONSIDERAÇÕES FINAIS SOBRE SANTO DOMINGO}

Com efeito, é próprio da História eclesiástica seus momentos de inflexão, onde as divergências em determinado momento se entrecruzam, e obviamente que um entrecruzamento eclesiológico é marcado por tensões que permeiam a vida pastoral das Igrejas locais, tensões essas não raro presentes em dicotomias e miopias eclesiais que causaram fissuras entre pastorais e movimentos. A tensão eclesiológica é saudável, na medida em que é um alerta a fim de direcionar toda tensão num novo sentido missionário, que contemple as potencialidades eclesiais e missionárias.

Não raro, a missão corrige a falta de comunhão, pois é ao pôr os pés na estrada, que se podem sentir as condições de viagem. Dessa interação eclesiológica é que surge uma nova evangelização latino-americana. Eis Santo Domingo, o encontro da Nova Evangelização com a Igreja Latino Americana e Caribenha, contendo os instrumentais de uma postura crítica à uma caminhada própria de uma Igreja fonte, porém com espaço suficiente para que permaneça na Igreja o que vem de Deus. Essa é a configuração exatamente anterior à Aparecida, onde esta, agora servirá de conclusão de um longo processo de avaliação crítica da Igreja Latino Americana e da Nova Evangelização, aprofundando o processo de interação eclesiológica e missiológica na América Latina e Caribe. 


\section{IGREJA E MISSÃO NA $5^{\text {a }}$ CONFERÊNCIA GERAL DO EPISCOPADO LATINO AMERICANO E CARIBENHO: APARECIDA (2007)}

"Discípulos e missionários de Jesus Cristo para que nossos povos nele tenham vida! Eu sou o caminho, a verdade e a Vida" (Jo 14,6)

A $5^{\text {a }}$ Conferência realizada em Aparecida se inicia com as palavras do Papa Bento XVI, onde menciona que a "a Igreja é a nossa casa!" ${ }^{21}$, onde somos chamados a preservar, ter fé que precisa estar alicerçada na base sólida da formação doutrinal e espiritual, contribuindo para a construção de uma sociedade mais justa, mais humana e cristã.

No discurso de inauguração, o Santo Padre lembra que a fé anima o nosso continente há mais de cinco séculos, e é no encontro com a fé que diferentes culturas descobriram, pois "conhecer e acolher Cristo, o Deus desconhecido que seus antepassados sem saber buscavam em suas ricas tradições religiosas"22.

Dessa rica integração cultural nasceu a religiosidade popular que se expressa nas diversas formas de devoções. O Papa recorda que a $\vee$ Conferência é a continuidade das quatro anteriores, com o impulso da evangelização.

A Igreja tem a missão de animar a fé do povo, recordando a eles que através de seu Batismo, estão chamados a serem discípulos e missionários de Jesus Cristo.

Os bispos presentes na Conferência refletiram sobre o sofrimento e as alegrias de nossos povos, e mencionaram que "iluminados pelo Cristo, o sofrimento, a injustiça e a cruz nos desafiam a viver como Igreja samaritana, recordando que a evangelização vai unida sempre à promoção humana e à autêntica libertação Cristã" ${ }^{23}$. Recordam que "o Homem e Mulher são imagem e semelhança de Deus".

\footnotetext{
${ }^{21}$ Cf. Oração do Santo Rosário e Encontro com os sacerdotes, os religiosos, as religiosas, os seminaristas e os diáconos na Basílica do Santuário de Aparecida (12 de maio de 2007). Documento de Aparecida pg. $261 \S 6$

22 Cf. Discurso Inaugural, $\mathrm{n}^{\circ}$. 1. .

${ }^{23}$ Cf. Documento de Aparecida, $n^{\circ} .26$.
}

142 Revista de Cultura Teológica - V. 16 - N. 64 - JUL/SET 2008 
O catolicismo deve assumir a sua missão, sendo seguidor dos passos de Jesus, sendo servidor e evangelizando. A realidade apresenta as mudanças constantes com alcance global, a ciência e a tecnologia avançam em ritmo acelerado, suas conseqüências nem sempre são benevolentes, a globalização nos une e ao mesmo tempo nos separa de maneira brutal, "os meios de comunicação de massa apresentam novas imagens atrativas e cheias de fantasias" ${ }^{24}$.

As tradições culturais não são mais heranças familiares, assim o cristão deve estar atento para que o anúncio de Jesus Cristo não seja diluído nas ondas da globalização e sim anunciá-lo com ardor de missionários e missionárias que acreditam que somente através da vida em Jesus e vivendo seus ensinamentos, se poderá caminhar para uma sociedade onde reine a justiça, a paz e a esperança.

$\mathrm{O}$ individualismo, reflexo do fenômeno social vigente enfraquece a vida comunitária, como menciona o documento que "deixa-se de lado a preocupação pelo bem comum para dar lugar à realização imediata dos desejos dos indivíduos" ${ }^{25}$.

A Igreja é convidada a resgatar a sua essência, a missão, tendo como modelo as primeiras comunidades cristãs, formando seus presbíteros, consagrados, consagradas, leigos, com renovado ardor missionário, superando os desafios da sociedade hodierna, vivendo os sacramentos, sobretudo alimentando-se na Eucaristia, sustento na caminhada, pois "esta firme decisão missionária deve impregnar todas as estruturas eclesiais e todos os planos de pastorais de dioceses, paróquias, comunidades religiosas, movimentos e de qualquer instituição da Igreja" ${ }^{26}$.

"A fisionomia da Igreja Latino-americana é marcada pela opção pelos pobres", assim afirmou João Paulo II, dirigindo-se ao continente, sustentando que "converter-se ao Evangelho para o povo cristão que vive na América, significa revisar todos os ambientes e dimensões de sua vida, especialmente tudo o que pertence à ordem social e a obtenção do bem comum"27.

\footnotetext{
24 Documento de Aparecida, n. 35

25 Ibidem $n^{\circ} .44$

26 Ibidem capítulo 7 nº 365

27 Ibidem capítulo 08- $\mathrm{n}^{\circ} .391$
} 
A Conferência tem como proposta animar os missionários e missionários do continente, a assumirem sua missão de discípulos e discípulas, evangelizando, anunciando a Jesus Cristo e seu projeto de amor, justiça e solidariedade para que estes povos tenham vida.

A população latino-americana tem muitas características em comum, como a linguagem, a colonização européia, a cultura e a religião, características estas que a unem para a evangelização, pois "a Igreja cresce, não por proselitismo, mas por atração; como Cristo "atrai tudo para si" com a força do seu amor". A Igreja "atrai" quando vive em comunhão, pois os discípulos de Jesus serão reconhecidos se amarem uns aos outros como ele os amou "28.

A Igreja peregrina, missionária na sua origem, através da força da Santíssima Trindade comunidade de amor, adquire novo ardor missionário no continente através da realização da $5^{\mathrm{a}}$ Conferência. Os fiéis são convidados como cristãs e cristãos, a viver a Igreja, a comunhão a serviço do povo sofrido que clama por justiça, que tem a esperança da paz, que tem a solidariedade enraizada dentro de si, que anseia pelo anúncio do Deus da vida.

Atualmente muitos católicos vivem desorientados diante de várias mudanças culturais, e a responsabilidade de Igreja é denunciar "claramente estes modelos antropológicos incompatíveis com a natureza e dignidade do homem" ${ }^{29}$, a pessoa humana é o centro da vida social e cultural, é necessário resgatar a dignidade do humano que é imagem e semelhança de Deus.

Diante dos desafios atuais, a Igreja presente no mundo como sinal da presença de Deus, portadora do depósito da fé, continuadora da missão de Jesus Cristo confiada a Pedro e hoje representada pelo Papa Bento $\mathrm{XVI}$, tem como missão anunciar Jesus Cristo, através da missão confiada aos primeiros discípulos e discípulas nas comunidades primitivas cristãs e atualmente anunciada por todos nós cristãos e cristãs presentes neste continente marcado pelo sofrimento, mas abençoado por Deus, sob a proteção da Virgem de Guadalupe, Maria Santíssima.

\footnotetext{
28 Ibidem, nº 159

29 Documento de Aparecida, $\mathrm{n}^{\circ} .480$
}

144 Revista de Cultura Teológica - V. 16 - N. 64 - JUL/SET 2008 


\section{CONCLUSÃO}

A partir da análise deste conteúdo tão rico apresentado pelas cinco conferências do episcopado latino-americano e caribenho, pós-Vaticano II, se percebe a preocupação inerente da Igreja na obra da Evangelização de todos os povos. Uma vez que estas conferências não se caracterizam como momentos de discussão dogmática nem tampouco teológica, elas vão de fato, se caracterizar por serem justamente momentos em que a Igreja convoca-se a si própria para avaliar e discutir a razão fundamental do estar no mundo: a evangelização.

Analisando os contextos em que se inseriram a cada conferência, a Igreja pode exaltar suas conquistas, mas sobretudo, pontuar e refletir suas carências e deficiências: da escassez do clero, assunto pontual da Conferência do Rio de Janeiro em 1955, passando pela opção preferencial pelos pobres em Medellín, bem como a promoção humana, a preocupação com a família e juventude em Puebla, com o surgimento das CEB's, a proposta da Nova Evangelização em Santo Domingo, até Aparecida: "Discípulos e missionários de Jesus Cristo, para que nossos povos N'Ele tenham vida"; foram sempre momentos ricos, do sopro do Espírito que conduz sua Igreja presente neste mundo para ser sinal de esperança e da presença do reino.

A partir da última Conferência realizada em Aparecida, todos são convocados como batizados, a assumirem com seriedade a sua vocação batismal, numa Igreja toda ela ministerial, primeiramente a serviço dos que mais sofrem, ao mesmo tempo profética: anunciando a boa nova e denunciando as injustiças. Portanto, ser discípulo como propõe a Conferência, é estar perto do Senhor, conhecer Jesus Cristo, o ressuscitado, fazer com Ele uma experiência de vida, não apofática, mas como lembra o Papa João Paulo II, em sua encíclica Ecclesia de Eucharistia, um encontro a partir da palavra anunciada e vivida, valorizando a Eucaristia como o momento supremo do encontro com o Senhor e com os irmãos para formar comunidade que, alimentada deste mesmo pão, reconhece o seu Senhor nos que mais sofrem: isto é ser missionário.

Prof. Dr. Pe. Ney de Souza

É coordenador e professor do Programa de Pós-Graduação em Teologia da Pontifícia Faculdade de Teologia Nossa Senhora da Assunção/SP 


\section{BIBLIOGRAFIA}

JOÃO PAULO II. Redemptoris missio. Sobre a Validade permanente do mandato missionário. 12/07/1990.

COMPÊNDIO DO CONCÍLIO VATICANO II. Petrópolis: Vozes, 1968.

DOCUMENTOS DO CELAM. Rio- Medellín- Puebla- Santo Domingo, São Paulo: Paulus, 1993.

DOCUMENTO DE APARECIDA. Texto conclusivo da V Conferência Geral do Episcopado Latino-Americano e do Caribe. São Paulo: Paulus, 2007.

CATÃO, FRANCISCO. Santo Domingo - Significação e Silêncio. São Paulo: Paulinas, 1992.

KLINGE, German Doig. De Rio a Santo Domingo. Lima: Vida y Espiritualidad, 1993.

LIBÂNIO, João Batista. A volta à grande disciplina: reflexão teológico-pastoral. São Paulo: Loyola, 1984.

Conferências Gerais do Episcopado Latino-Americano do Rio de Janeiro a Aparecida. São Paulo: Paulus, 2007.

PADIN, C.; GUITIÉRREZ G. ; CATÃO F. Conclusões da Conferência de Medellín -1968. Trinta anos depois, Medellín é ainda atual? São Paulo: Paulinas, 1998.

SOUZA, Ney de. Temas de Teologia Latino americana. Sao Paulo Paulinas, 2007.

BEOZZO, José Oscar. Medellín: Inspiração e raízes. Revista Eclesiástica Brasileira, Petrópolis, 232 (1998) 822-850...

PERSPECTIVA TEOLÓGICA, n. 16. Ed. O Lutador: Belo Horizonte, 1984.

SANTOS, Benedito Beni dos. A identidade da Igreja Latino-Americano de Medellín a Santo Domingo. Revista de Cultura Teológica. São Paulo: PFTNSA. 15 (1993). 07-17.

LORSCHEIDER, Aloísio. A teologia subjacente às conclusões de Santo Domingo. Cadernos da ESTEF. Porto Alegre-RS: Estef, 2005, v. 03, p. 20ss.

A Caminho da $5^{\text {a }}$ Conferência Geral do Episcopado LatinoAmericano e Caribenho. Retrospectiva histórica. Editora Santuário, pp. 21-40 e 88-92.

MORÁS, F. Evangelização das classes médias e solidariedade com os pobres: o legado de Medellín. In: Revista Eclesiástica Brasileira, Petrópolis, 232 (1998).

STRINGHINI, Pedro Luiz. Oitava assembléia geral da Sociedade de Teologia e Ciências da Religião - SOTER - reflexão sobre Santo Domingo. In: Revista de Cultura Teológica. São Paulo: PFTNSA. 15 (1993) 107-112.

146 ReVISTA de Cultura TeOlógICA - v. 16 - N. 64 - JUL/SET 2008 